$\xi=-1$

\title{
Guest Satisfaction and Revisit Intention of Muslim Friendly Hotels in Malaysia
}

\author{
Myzatul Aini Ma'asor@ Mansor, Ahmad Puad Mat Som*, Aziz Amin, Yahaya Ibrahim, Norsuhaily Abu Bakar, \\ Yendo Afgani @ Eusoff \\ Faculty of Applied Social Sciences, Universiti Sultan Zainal Abidin, Gong Badak Campus, 21300 Kuala Nerus, Terengganu, Malaysia \\ *Corresponding author E-mail: puadms@unisza.edu.my
}

\begin{abstract}
The hotel industry has remained one of the most competitive industries in the 21st century, and there is a great deal of study being done on guest satisfaction and the consequent effects it has on guest loyalty and financial performance. Many studies have demonstrated that hoteliers that have more satisfied guests experience higher guest loyalty and perform better financially compared to their competitors, ensuring continuity of their business in the long term. The overwhelming demand for quality products and services among Muslim travelers in recent years has led to the establishment of Muslim Friendly Hotels (MFH) in Malaysia and other Muslim countries. It is widely believed that Muslims perceive Islam as something more than just a religion - it is a way of life. Hence, the religion shapes their consumption behavior even during travel. Currently, very little research has examined the influence of satisfaction on revisit intention among guests staying at MFH, specifically in Malaysia. Preliminary findings from a survey of hotel guests indicate that there is a significant relationship between guest satisfaction and revisit intention, which further explains the importance of desirable hotel attributes in influencing hotel selection and a guest's experience.
\end{abstract}

Keywords: Satisfaction; Revisit Intention; Muslim Friendly Hotel.

\section{Introduction}

Revisit intention is the most important measure for maintaining hotel's revenue. In [1] agreed that the revisit intention is similar to the concept of repurchase which has become significant enough to serve as the main body in modern-day marketing strategies. In addition, a basic business goal is that the more a customer is satisfied the more he is willing to buy. In the hospitality industry, a number of researchers have applied satisfaction-related theories and methods as one of the most frequently examined topics, and many empirical studies show that customer satisfaction is a strong indicator of intentions to revisit and recommend the destination to other people [2-4]. Moreover, repeat guests are an essential asset to any successful hotel business. The most effective way to retain repeat guests is to attain high customer expectations or to provide a service that exceeds the customers' expectations [5].

Customer satisfaction is the customer's response to the quality of the service he or she receives. Service quality, on the other hand, is the provider's means of achieving customer. Quality was soon the focus for the development of measures of satisfaction [6]. Service quality, satisfaction, and behavioral intentions are critical concepts in the field of marketing - as means of measuring success in a variety of organizations [7]. One of the biggest challenges for managers in the hotel industry is to provide and sustain customer satisfaction [8].

Nowadays, halal tourism is becoming one of the new products in the tourism industry which can be significant either to the Muslim or non-Muslim market [9]. Islamic tourism can be conceptualized from three different perspectives, economic, cultural and religious [10]. In addition, for a product(s) to be Halal (compliant with Islamic Shari'ah), it must meet the requirements of Shari'ah as found in its sources. The two main sources of Islamic Shari'ah are the Quran (Muslims holy book) and the Sunnah (which are the teachings and guidance of Prophet Mohammad peace be upon him) [11] Islamic tourism is still in an infancy stage in Malaysia, but the demands from the Middle East are growing especially during the summer break period July to September each year. Malaysia has brought in halal and Islamic tourism concept to practice to their travel and tour packages, halal activities, halal food and beverage and halal in hotels in pleasing demand and need among Muslims travelers [12]. 'The concept of Islamic tourism is not limited to spiritual tourism, but it extends to all forms of tourism except those that go against Islamic values'. Therefore, the two concepts are vague and definitional ambiguities in terms of the Islamic law, the target customers (i.e. Muslims or non-Muslims), the location of activity (i.e. destination attributes), the product and service offered (i.e. food, facilities), and the purpose of travel [13]. In Malaysia, numerous studies have been conducted relating to guest satisfaction, which mostly examined service quality, perceived value and customer expectations. However, there is a limited study that evaluates the correlation between satisfaction and revisit intention, especially in Muslim Friendly Hotel (MFH). Therefore, the purpose of this research is to examine the relationship between hotel guest satisfaction and their intention to return to a hotel, among guests who have experienced staying at MFH in Malaysia. Also, the objective of this study is to determine whether there is a relationship between both variables. 


\section{Literature Review}

\subsection{Muslim Friendly Hotel in Malaysia}

Malaysia was known as a secure destination for Muslim travelers that can cater to their special needs. These special needs include the abundance of prayer facilities throughout the country, hala food and beverages and even the Islamic banking for business transactions [18]. Moreover, in [13] agreed that availability of Muslim-friendly hotel is considered one of the most important attributes that attract Muslim travelers and encourage them to visit the destination. Muslim Friendly Hotel (MFH) can be defined as a hotel that can fulfill at least basic needs of Muslim guests such as Qiblah direction, halal food, prayer facilities and services Industry practitioners should also apply attributes such as not allowing any alcohol in the premises; providing a Qur'an, prayer mat and prayer schedule in the rooms; and equipping the bathrooms with bidets for use in taking ablution as an advance for Syariah Compliant Hotel.

To be able to claim as being MFH, practitioners must offer attributes that can fulfill Muslims' wants, especially when they need to perform daily prayers five times a day. Malaysia previously established standards such as MS1500:2009 (Malaysian Standard of Halal Food-Production, Preparation, Handling and Storage) and MS1900:2005 (Malaysian Standard for Quality Management System-Requirements from Islamic Perspectives) [14]. Recently, the Department of Standards Malaysia under the Ministry of Science, Technology and Innovation with the involvement of Department of Islamic Development Malaysia (JAKIM), including other relevant government agencies, universities, industries and non-governmental organisations developed MS2610:2015 (Muslim friendly hospitality services requirements) - which are set up to preserve and protect the integrity of "Islamic tourism products and services" [15].

Not only can the concept be applied to hotel management, but also for the whole operation, including the products and services being offered. The hotel's operations must be found upon the Qur'an the Sunnah (the practices and sayings of Prophet Muhammad PBUH), and Fiqh (jurisprudence, the opinions of Muslim legal scholars) [16].

De Palma Ampang is the first hotel in Malaysia to offer services that comply with Shariah principles. This is evidenced by the review of this hotel as the first hotel to be recognised as a $\mathrm{MFH}$ in Malaysia's hotel industry [17]. De Palma Hotel can be a benchmark since it has successfully become entirely Muslim-friendly [18]. This has then been followed by the Bluewave Hotel, Shah Alam; the PNB Perdana Hotel and Suites on The Park, Kuala Lumpur; and the Adya Hotel, Langkawi. These hotels are certified by the JAKIM and implement all the attributes that are in line with Syariah principles.

\subsection{Guest Satisfaction}

In [19] defined customer satisfaction as a guest's postconsumption judgment of a product or service that can be measured by measuring guests' evaluation of performance on specific attributes. Satisfaction can be a substantial measurement for the hospitality industry in marketing products and services. Satisfaction is a subjective judgment and can be assessed after each purchase and consumption experience. Satisfaction is also a final construct of the purchase decision-making process [20]. In [21] agreed that success in the hotel business depends on understanding of the key factors in determining customer satisfaction. Meanwhile, another study indicated that poor facilities or inadequate comfort levels in the hotel room itself were specifically associated with lower levels of satisfaction [22].

There have been several studies about guest satisfaction related to hospitality industry. In [23] examined the relative importance of 33 hotel traits from 7 hotel factors (staff service quality, room quality, general amenities, business services, value, security and IDD facilities) related to traveler' overall satisfaction levels with their hotel vacations in Hong Kong and the possibility of returning to the same hotel in their following trips. Expectation confirmation theory [24] states that satisfaction is a continuing comparison between what was expected before purchase and the actual level of product/service performance. In measuring service quality and tourist satisfaction, it is important to understand the different issues involved in service quality, tourist satisfaction and revisits intentions and the interactions of these issues [25].

Globally, there is growing demand for better quality products and services including hotel services [26], as such tourist satisfaction is a key ingredient for the persistence and success of the hotel industry. Therefore, hotels need to differentiate their service offerings by meeting the needs of their customers better, improving customer satisfaction and delivering service quality that is higher than that provided by competitors [27, 28]. Some authors $[29,30]$ have pointed out that behavioral intentions may predict behavior, implying that customer service quality constructs are relevant to behavioral intentions.

To satisfy a guest, hotelier first should understand what they need. Especially for Muslim guests, hotel operator must know their daily routine. By fulfilling their requirements, the hotelier can measure guests' future behavior like their intention to revisit again at the same destination. In [31] also mentioned that accommodation providers should take into consideration the religious beliefs of their Muslim patrons in order to fulfil their needs and maximize customer satisfaction.

\section{Revisit Intention}

It is crucial for hotel practitioners to encourage their guests to keep revisiting the hotel in future. In [20] stated that first-timers' revisit intentions may be influenced mainly by destination performance as a whole because of their initial stay, while repeaters' intentions may be influenced largely by promotional efforts to recall their positive memory and by disseminated information on new attractions. Also, in [26] ascertained that there exist strong positive relationships between service quality and tourist satisfaction and revisit intention. This invariably suggests that if overall service quality is high, all things being equal, tourist satisfaction will be high. Previous study by [32] found that the number of previous visits significantly influenced future intention. Several studies also supported almost unanimously that tourist satisfaction positively affected revisit intention [33, 34].

Numerous studies have highlighted the relationship between satisfaction and intention to revisit. Satisfaction was a direct antecedent of short-term revisit intention, but not of mid-term or of long-term revisit intention [35]. Thus, management should take special care of visitor satisfaction because satisfied visitors will return to experience a similar satisfaction. Moreover, a high level of satisfaction will lead to increased revisit intentions. This is also supported by [36], that relationship of both guest satisfaction and return intention were significant.

\section{Methodology}

\subsection{Instrument Design}

This preliminary study was developed based on feedback from respondents who have experienced a stay at MFH in Malaysia. Primary data was collected directly from customers through a questionnaire. A total of 120 questionnaires were distributed and 103 were returned. The items in the instrument were adapted from previous studies investigating the relationship between satisfaction [37] and revisit intention [38]. Satisfaction was measured by ten questions, to examine the guests' overall satisfaction throughout their experience in hotels with Islamic attributes. Meanwhile, revisit intention was measured by five items, where that hotel guests were asked to rate based upon their intention to revisit the hotel in the future. Attributes and satisfaction were quantified using a fivepoint Likert-type scale. Respondents were asked to rate their 
degree of agreement of the statements. Point 1 represents "strongly disagree", and goes up to 5 which represents "strongly agree". This study employed the Statistical Packages for Social Sciences (SPSS Version 21) to analyze and process the collected data.

\subsection{Demographic Information}

Respondents consisted of $58.3 \%$ male and $41.7 \%$ female. The majority of respondents ranged in age from 21 to 30 (45.6\%), followed by ages of 31 to 40 (35.9\%). Muslims made up $96 \%$ of total respondents, meanwhile Christians and Buddhists each were $2 \%$ respectively. Malaysians made up the most of the participants (95\%). As this study sample is from hotels' guests who have experienced the MFH concept, it is recorded that $74 \%$ of the respondents had stayed at MFH at least once and the majority of them had their last visit a year ago (29\%). $47.6 \%$ chose leisure as their main purpose of the trip and $28.2 \%$ of the respondents were on a business trip. Four main travel reasons were identified: religious, leisure, business and medical.

\section{Results and Discussion}

The objective of the study is to examine whether there is a relationship between satisfaction and revisit intention among MFH guests in Malaysia. As shown in Table 1, the scale was first subjected to a reliability analysis to assess the quality of the measure [39]. Hence, to test reliability and internal consistency of both variables, a Cronbach alpha was calculated. The reliability value of the instruments used are $\alpha=0.965$ (guest satisfaction) and 0.949 (revisit intention). These values are considered good, the closer Cronbach's alpha is to 1 , the higher the internal consistency reliability [40].

Table 1: Reliability Statistics

\begin{tabular}{|c|c|c|}
\hline Variables & N of Items & Cronbach's Alpha \\
\hline Guest Satisfaction & 10 & .965 \\
\hline Revisit Intention & 5 & .949 \\
\hline
\end{tabular}

The findings are shown in Table 2, where it is evident that there was a significant relationship between variables since the values are less than $0.01(\mathrm{p}<0.01)$. In other words, the more the MFH guests are satisfied with the Islamic attributes, the more chance that they will have the intention to revisit the hotel. Correlation (**) refers to the relationship that is at a 99 percent confidence level. This significant level is generated when the Sig values obtained are more or less than 0.01 . This study analyses the data using the Pearson correlation, where the Pearson coefficients are used to determine the relationship between two variables in which the lower scale (or both) is on the scale of the interval [41]. Table 2 also shows that the value of $r$-square is 0.79 , which means that it is a positive correlation for both constructs and results in a strong correlation (in the range $0.71-0.90$, as per Table 3 ) by [43]. The positive and negative signs on the correlation coefficient only show the direction of the relationship between the two variables, and does not describe the strength of the relationship [41]. The strength of the relationship is represented by the value of the coefficient of correlation.

Table 2: Results of Relationships between Variables

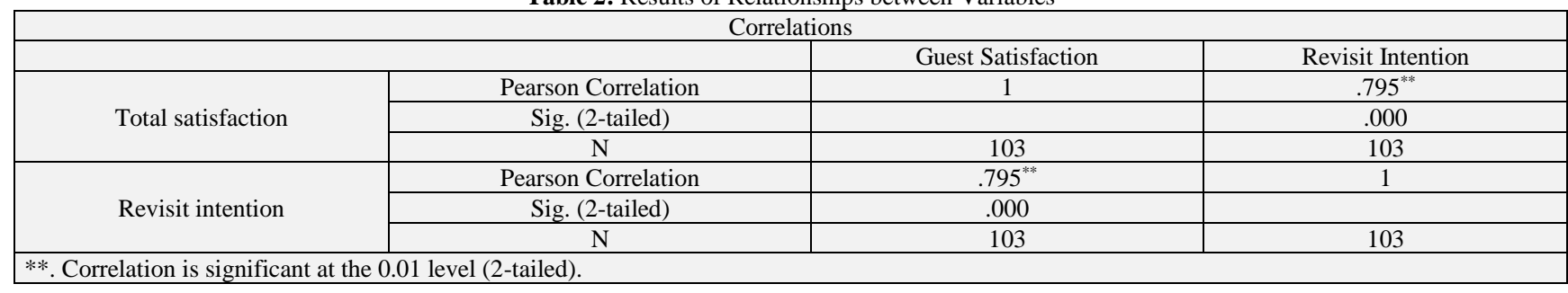

Table 3: The Strength of Relationships Based on Correlation Value

\begin{tabular}{|c|c|}
\hline Correlation Value & Relationship Interpretation \\
\hline $0.00-0.20$ & Very Weak \\
\hline $0.21-0.40$ & Weak \\
\hline $0.41-0.70$ & Moderate \\
\hline $0.71-0.90$ & Strong \\
\hline $0.91-1.00$ & Very Strong \\
\hline
\end{tabular}

\section{Conclusion}

The findings of this study exemplify that the intention to revisit can be significantly influenced by the overall total satisfaction from the first visit to MFH in Malaysia. This study concludes that guest satisfaction is important to create positive future behavior of the hotels' guests. Hoteliers should know better what actually guests need especially religious features to cater this niche market. More attention should be given by hotel operators to the innovation of the services in terms of offering attributes that are in line with Syariah principles, which can then lead to an increased level of guests' satisfaction. Moreover, hoteliers should not simply claim their hotel as MFH for marketing reasons; this situation will bring about poor feedback if and when they cannot fulfill Muslims' religious needs. The MFH concept is universal and can also benefit non-Muslim guests - an example is a halal food. To be certified as halal, hoteliers need to make sure that all the food production, preparation, handling, and storage strictly follows the Malaysian Standard (MS) 1500:2009. Apart from that, alcohol and gambling should be banned, a no smoking policy should be in place, both of which are good for health, physically and mentally [44].
Travelers tend to revisit a destination based on their previous experience. For a hotel, satisfaction can give guests a reason to become loyal, especially when they receive services beyond their expectations. This is supported by [35] that travel destinations could motivate travelers to revisit within a year or so by maximizing traveler satisfaction. By maintaining old customers is better than searching a new one that may have different needs $[20,35$, 42]. Finally, it is recommended that future studies consider using larger sample size and to address the issue of how individuals who have never visited MFH.

\section{Acknowledgement}

It is gratefully acknowledged that this research project, funded by Universiti Sultan Zainal Abidin under Grant No: FRGS/1/2015/WAB12/UNISZA/01/1, was led by Professor Dr. Ahmad Puad Mat Som (Project Leader). The authors would also like to thank the Research Management, Innovation and Commercialization Centre, Universiti Sultan Zainal Abidin, Terengganu, Malaysia for providing the financial assistance to sup-port the publication fee of this article.

\section{References}

[1] Luo, S. J., \& Hsieh, L. Y. (2013). Reconstructing revisit intention scale in tourism. Journal of Applied Sciences, 13(18), 3638-3648.

[2] Back, K.-J., \& Parks, S. C. (2003). A brand loyalty model involving cognitive, affective, and conative brand loyalty and customer satisfaction. Journal of Hospitality and Tourism Research, 27(4), 419-435. 
[3] Jeong, M., Oh, H., \& Gregoire, M. (2003). Conceptualizing web site quality and its consequences in the lodging industry. International Journal of Hospitality Management, 22(2), 161-175.

[4] Mattila, A. S., \& Mount, D. J. (2003). The impact of selected customer $\mathrm{c}$ and response time on e-complaint satisfaction and return intent. International Journal of Hospitality Management, 22(2), 135-145

[5] Kim, T. (Terry), Kim, W. G., \& Kim, H. B. (2009). The effects of perceived justice on recovery satisfaction, trust, word-of-mouth, and revisit intention in upscale hotels. Tourism Management, 30(1), 51-62.

[6] Gilbert, D., \& Horsnell, S. (1998). Customer satisfaction measurement practice in United Kingdom hotels. Journal of Hospitality and Tourism Research, 22(4), 450-464.

[7] Lee, J., Graefe, A. R., \& Burns, R. C. (2004). Service quality, satisafction, and behavioral intention among forest visitors. Journal of Travel and Tourism Marketing, 17(1), 73-82.

[8] Suma, S., \& Susithra, V. (2014). A study on service quality and customer satisfaction towards hotels in Tirupur district. Indian Journal of Applied Research, 4(9), 1-4.

[9] Wan Zulkifli, W. S., Ab Rahman, S., Awang, K. W., \& Che Man, Y. B. (2011). Developing the framework for halal friendly tourism in Malaysia. International Business Management, 5(6), 295-302.

[10] Al-Hamarneh, \& Steiner, C. (2004). Islamic tourism: Rethinking the strategies of tourism development in the Arab World after September 11, 2001. Comparative studies of South Asia, Africa and the Middle East, 24(1), 173-182.

[11] El-Gohary, H. (2016). Halal tourism, is it really halal? Tourism Management Perspectives, 19, 124-130.

[12] Othman, N., Mohd Taha, R., \& Othman, S. (2017). Maqasid Al shariah in the governance and management strategy of Islamic tourism businesses. Proceedings of the International Conference on Maqasid al-Shariah in Public Policy and Governance, pp. 1-18.

[13] Battour, M., \& Ismail, M. N. (2015). Halal tourism: Concepts, practises, challenges and future. Tourism Management Perspectives, 19, 150-154.

[14] Samori, Z., \& Abd Rahman, F. A. (2013). Establishing shariah compliant hotels in Malaysia: Identifying opportunities, exploring challenges. West East Journal of Social Sciences, 2(2), 95-108.

[15] COMCEC. (2016). Muslim friendly tourism: Understanding the demand and supply sides in the OIC member countries. COMCEC Coordination Office.

[16] Mohd Yusof, M. F., \& Muhammad, M. Z. (2010). Introducing shariah compliant hotels as a new tourism product: The case of Malaysia. Proceedings of the Entrepreneurship Vision 2020 Innovation, Development Sustainability, and Economic Growth, pp 1142-1146.

[17] Sahida, W., Rahman, S. A., Awan, K., \& Man, Y. C. (2011). The implementation of shariah compliance concept hotel: De Palma Hotel Ampang, Malaysia. Proceedings of the 2nd Internationa Conference on Humanities, Historical and Social Sciences, pp. $138-142$.

[18] Mohamad, S. A., Yahya, W. K., Azer, I., \& Che Hamzah, H. (2013) The opportunities and challenges to be a shariah compliant hotel: A case of LKPP De Rhu Beach Resort. Konaka, 2010, 2010-2014.

[19] Gundersen, M. G., \& Olsson, U. H. (1996). Hotel guest satisfaction among business travelers: What are the important factors? Cornell Hotel and Restaurant Administration Quarterly, 37, 272-281

[20] Um, S., Chon, K., \& Ro, Y. (2006). Antecedents of revisit intention. Annals of Tourism Research, 33(4), 1141-1158.

[21] Poon, W. C., \& Low, K. L. T. (2005). Are travellers satisfied with Malaysian hotels? International Journal of Contemporary Hospitality Management, 17(3), 217-227.

[22] Zhou, L., Ye, S., Pearce, P. L., \& Wu, M. Y. (2014). Refreshing hotel satisfaction studies by reconfiguring customer review data. International Journal of Hospitality Management, 38, 1-10.

[23] Choi, T. Y., \& Chu, R. (2001). Determinants of hotel guests' satisfaction and repeat patronage in the Hong Kong hotel industry. International Journal of Hospitality Management, 20(3), 277-297.

[24] Oliver, R. L. (1977). Effect of expectation and disconfirmation on postexposure product evaluations: An alternative interpretation. Journal of Applied Psychology, 62(4), 480-486.

[25] Olorunniwo, F., Hsu, M. K., \& Udo, G. J. (2006). Service quality, customer satisfaction, and behavioral intentions in the service factory. Journal of Services Marketing, 20(1), 59-72.

[26] Amissah, E. F. (2013). Tourist satisfaction with hotel services in Cape Coast and Elmina, Ghana. American Journal of Tourism Management, 2(1A), 26-33

[27] Jamal, A., \& Anastasiadou, K. (2009). Investigating the effects of service quality dimensions and expertise on loyalty. European
Journal of Marketing, 43(3/4), 398-420.

[28] Reichheld, F. E., \& Sasser, W. E. (1990). Zero defects: Quality comes to services. Harvard Business Review, 68, 105-113.

[29] Zeithaml, V. A., Berry, L. L., \& Parasuraman, A. (1996). The behavioral consequences of service quality. Journal of Marketing, 60(2), 31-46.

[30] Zhang, X., \& Prybutok, V. R. (2005). A consumer perspective of eservice quality. IEEE Transactions on Engineering Management, 52(4), 461-477.

[31] Stephenson, M. L. (2014). Deciphering "Islamic hospitality": Developments, challenges and opportunities. Tourism Management, 40, 155-164

[32] Mazursky, D. (1989). Past experience and future tourism decisions. Annals of Tourism Research, 16(3), 333-344.

[33] Tomas, S., Scott, D., \& Crompton, J. (2002). An investigation of the relationships between quality of service performance, benefits sought, satisfaction and future intention to visit among visitors to a zoo. Managing Leisure, 7(4), 239-250.

[34] Yoon, Y., \& Uysal, M. (2005). An examination of the effects of motivation and satisfaction on destination loyalty: A structura model. Tourism Management, 26(1), 45-56.

[35] Jang, S. C., \& Feng, R. (2007). Temporal destination revisit intention: The effects of novelty seeking and satisfaction. Tourism Management, 28(2), 580-590.

[36] Berezan, O., Raab, C., Yoo, M., \& Love, C. (2013). Sustainable hotel practices and nationality: The impact on guest satisfaction and guest intention to return. International Journal of Hospitality Management, 34(1), 227-233.

[37] Ai Cam, T. T. (2011). Explaining tourists satisfaction and intention to revisit Nha Trang, Viet Nam. University of Tromso.

[38] Yong, C. K., Siang, D. O. Chee, Lok, T. W., \& Kuan, W. Yin. (2013). Factors influencing dining experience on customer satisfaction and revisit intention among undergraduates towards fast food restaurants. PhD thesis, University Tunku Abdul Rahman.

[39] Yuksel, A. (2001). Managing customer satisfaction and retention: A case of tourist destinations, Turkey. Journal of Vacation Marketing, $7(2), 153-168$

[40] Sekaran, U., \& Bougie, R. (2010). Research methods for business: A skill building approach. John Wiley and Sons.

[41] Ibrahim, M. Y. (2010). Bimbingan cepat analisis data penyelidikan: Untuk pendidikan dan sains sosial. Bandar Ilmu.

[42] Dominici, G., \& Guzzo, R. (2010). Customer satisfaction in the hotel industry: A case study from Sicily. International Journal of Marketing Studies, 2(2), 3-12.

[43] Konting, M. M. (2000). Kaedah penyelidikan pendidikan. Dewan Bahasa dan Pustaka.

[44] Samori, Z., \& Sabtu, N. (2014). Developing halal standard for Malaysian hotel industry: An exploratory study selection and peerreview under responsibility of Centre for Islamic. Procedia - Social and Behavioral Sciences, 121, 144-157. 